\title{
Pengaruh Pembelajaran dengan Pendekatan Kontekstual terhadap Pemahaman Konsep Fisika Pada Siswa Kelas VIII SMPN 19 Palu
}

\author{
Aryani A Wahab, Amiruddin Hatibe dan Muhammad Jarnawi \\ Aryaniawahab8@gmail.com \\ Program Studi Pendidikan Fisika FKIP Universitas Tadulako \\ Jl. Soekarno Hatta Km. 9 Kampus Bumi Tadulako Tondo Palu - Sulawesi Tengah
}

\begin{abstract}
Abstrak - Tujuan penelitian ini adalah untuk mengetahui ada tidaknya pengaruh pembelajaran dengan pendekatan kontekstual terhadap pemahaman konsep fisika pada siswa Kelas VIII SMP Negeri 19 Palu. Hipotesis yang diajukan dalam penelitian ini yaitu terdapat pengaruh pembelajaran pendekatan kontekstual terhadap pemahaman konsep fisika pada siswa kelas VIII SMP 19 Palu. Populasi penelitian ini adalah seluruh siswa kelas VIII SMP 19 Palu. Pengambilan sampel dilakukan secara purposive sampling dengan sampel penelitian adalah kelas VIIIC sebagai kelas kontrol dan kelas VIIIA sebagai kelas eksperimen. Instrumen penelitian berupa tes pemahaman konsep yang telah divalidasi oleh validator ahli. Hasil analisa data dari rentang skor antara (0-20) diperoleh skor rata-rata kelas eksperimen 63,13 dengan standar deviasi 0,97 dan kelas kontrol diperoleh skor rata-rata 55,00 dengan standar deviasi 2,12. Berdasarkan uji hipotesis diperoleh $t_{\text {hitung }}>t_{\text {tabel }}$ yaitu $6,46>1,67$, dari taraf signifikasi $\alpha=0,05$ dengan demikian $\mathrm{H}_{1}$ diterima dan $\mathrm{H}_{0}$ ditolak. Hasil uji membuktikan bahwa terdapat perngaruh pemahaman konsep fisika antara kelas yang mengikuti pembelajaran dengan pendekatan kontekstual dengan siswa yang mengikuti pembelajaran konvensional.
\end{abstract}

Kata Kunci : pendekatan kontekstual, pemahaman konsep, cahaya

\section{PENDAHULUAN}

Pemahaman konsep fisika merupakan perangkat standar program pendidikan fisika yang mencerminkan kompetensi. Pemahaman konsep fisika adalah dasar bagi siswa untuk membangun kemampuan pemecahan masalah fisika. Seseorang siswa dituntut untuk memahami konsep atau fakta yang diketahuinya sehingga siswa dapat mengembangkan kemampuannya dalam menyelesaikan permasalahan yang ada. Sebagian besar konsep-konsep fisika merupakan konsep-konsep yang abstrak dan bahkan mereka sendiri tidak mengenali konsepkonsep kunci ataupun hubungan antara konsep yang diperlukan untuk memahami konsep tersebut sehingga siswa tidak dapat membangun pemahaman konsep pada awal mereka belajar fisika.

Salah satu tujuan pembelajaran fisika yaitu siswa mampu memahami konsep fisika, menjelaskan keterkaitan antara konsep dan megaplikasikan konsep secara luas dan tepat dalam memecahkan masalah. Untuk mencapai tujuan tersebut perlu dilakukan inovasi dalam proses pembelajaran diantaranya, dengan memberikan pengalaman belajar yang melibatkan mental dan fisik, pengalaman belajar tersebut terwujud melalui pendekatan, model, dan metode yang berpusat pada siswa.

Pendekatan kontekstual merupakan konsep belajar yang membantu guru mengaitkan antara materi yang diajarkannya dengan situasi dunia nyata siswa dan mendorong antara pengetahuan yang dimilikinya dengan penerapan dalam kehidupan mereka sebagai anggota keluarga dan masyarakat. Dengan konsep itu, hasil pembelajaran berlansung alamiah dalam bentuk kegiatan siswa bekerja dan mengalami. Bukan transfer pengetahuan dari guru ke siswa. Selain itu dalam pendekatan pembelajaran kontekstual siswa diberi kesempatan untuk memilih sub topik sendiri dan melakukan penyelidikan bersama dengan anggota kelompoknya. Guru bertindak sebagai fasilitator, melatih siswa dalam proses berfikir dan membentuk siswa mempunyai sikap ilmiah, sehingga siswa dapat menemukan fakta, membangun konsep dan teori-teori dengan keterampilan siswa sendiri yang akhirnya dapat meningkatkan pemahaman konsep siswa.

Pendekatan kontekstual (Contextual Teaching and Learning (CTL)) merupakan konsep belajar yang membantu guru mengaitkan antara materi yang diajarkannya 
dengan situasi dunia nyata siswa dan mendorong antara pengetahuan yang dimilikinya dengan penerapannya dalam kehidupan mereka sebagai anggota keluarga dan masyarakat. Dengan konsep itu, hasil pembelajaran diharapkan lebih bermakna bagi siswa. Proses pembelajaran berlansung alamiah dalam bentuk kegiatan siswa bekerja dan mengalami. Bukan transfer pengetahuan dari guru ke siswa. Strategi pembelajaran lebih dipentingkan daripada hasil. [1]

Contextual Teaching and Learning (CTL) adalah adalah suatu strategi pembelajaran yang menekankan kepada proses keterlibatan siswa secara penuh untuk dapat menemukan materi yang dipelajari dan menghubungkannya dengan situasi kehidupan nyata sehingga mendorong siswa untuk dapat menerapkannya dalam kehidupan mereka. Siswa mempelajari apa yang bermanfaat bagi dirinya dan berupaya menggapainya. Dalam upaya itu, mereka memerluan guru sebagai pengarah dan pembimbing. Jika guru mampu mengelola proses pembelajaran dan mampu menciptakan sistem pembelajaran yang efektif maka kualitas proses belajar akan tercapai. [2]

Pembelajaran konvensional tersusun dari dua kata, yaitu pembelajaran dan konvensional. Pembelajaran merupakan suatu proses kegiatan belajar mengajar yang bertujuan untuk membelajarkan siswa. Sedangkan konvensional mempunyai kata dasar konvensi yang berarti pemufakatan. Konvensional adalah suatu proses belajar mengajar yang umum digunakan disekolah. Dalam pembelajaran konvensional salah satu metode yang kerap digunakan yaitu metode ceramah, dimana metode tersebut adalah cara yang digunakan dalam mengajar. Metode Tanya jawab dan pemberian tugastugas untuk dikerjakan siswa dirumah juga dilakukan dalam metode ini. Pembelajaran konvensional adalah pembelajaran yang sering digunakan oleh guru disekolah. Pembelajaran konvensional pada umumnya lebih mengutamakan hapalan dari pada pengertian, menekankan pada keterampilan berhitung, mengutamakan hasil dari pada proses, dan pengajaran berpusat pada guru. [3]

Pemahaman memerlukan kemampuan menangkap makna dan arti dari suatu konsep. Tipe hasil belajar pemahaman lebih tinggi satu tingkat dari tipe hasil belajar pengetahuan hafalan. Pemehaman memerlukan kemampuan menangkap makna atau arti dari suatu konsep. Untuk itu diperlukan adanya hubungan antara pertautan antara konsep dengan makna yang ada dalam konsep tersebut. Hubungan antara konsep dengan makna tersebut akan menghasilkan perubahan perilaku. Pemahaman konsep adalah tingkat kemampuan yang diharapkan dari siswa untuk mampu memahami arti dari konsep, situasi, serta fakta yang diketahuinya. Dalam hal ini, siswa tidak hanya menghafal secara verbalitas, tetapi memahami konsep atau masalah. [4]

Tujuan penelitian ini adalah Untuk mengetahui ada tidaknya pengaruh pembelajaran dengan pendekatan kontekstual terhadap pemahaman konsep fisika pada siswa kelas VIII SMP Negeri 19 Palu.

\section{METODE PENELITIAN}

Penelitian ini menggunakan jenis penelitian eksperimen kuasi (quasi experiment) yang merupakan penelitian kuantitatif. Desain penelitian ini menggunakan rancangan pretestposttest yang tidak Ekuivalen "The Non Equivalen Pretest-Posttest Design". Jenis rancangan ini biasanya dipakai pada eksperimen yang menggunakan kelas-kelas yang sudah ada sebagai kelompoknya, dengan memilih kelas-kelas yang diperkirakan sama keadaannya.

Adapun desain penelitian menggunakan Rancangan Pretes-Posstes Desain penelitian ini digambarkan pada Tabel 1.

TABEL 1 DESAIN PENELITIAN

\begin{tabular}{cccc}
\hline Kelas & Pretest & Perlakuan & posstest \\
\hline Eksperimen & $\mathrm{O}$ & $\mathrm{X}$ & $\mathrm{O}$ \\
Kontrol & $\mathrm{O}$ & - & $\mathrm{O}$ \\
\hline
\end{tabular}

Keterangan :

O: Tes awal dan tes akhir

$\mathrm{X}$ : Perlakuan dengan pendekatan kontekstual

Populasi dalam penelitian ini yaitu seluruh siswa kelas VIII SMP Negeri 19 Palu tahun ajaran 2016/2017. Sampel dari penelitian ini adalah kelas VIIIA sebagai kelas eksperimen dan VIIIB sebagai kelas kontrol.

Penarikan sampel pada penelitian ini ditentukan dengan menggunakan tekhnik purposive sampling atau penentuan sampel dengan pertimbangan tertentu. Dua kelas yang dijadikan tempat penelitian ini adalah kelas yang diajar oleh guru yang sama. Satu kelas diberikan pembelajaran Pendekatan kontekstual (kelas eksperimen) dan satunya lagi menggunakan pembelajaran konvensional (kelas kontrol).

Instrumen yang digunakan dalam penelitian ini adalah tes essai. Tes digunakan untuk melihat kemampuan pemahaman konsep siswa. Tes essai sebanyak 5 soal yang dilakukan 
sebanyak dua kali pengujian, yaitu pada tahap awal sebelum perlakuan (pretest) dan tahap akhir setelah perlakuan (posttest). Untuk memperoleh tes yang standar, dilakukan validasi tes berupa validitas ahli.

Data yang diperoleh dari penelitian ini selanjutnya diolah dengan menggunakan uji statistik berupa uji normalitas, uji homogenitas, dan uji hipotesis (uji-t dua pihak).

\section{HASIL DAN PEMBAHASAN}

\section{A. Hasil Penelitian}

Instrumen ini terdiri dari Rencana Pelaksanaan Pembelajaran (RPP) dan Lembar Kerja Siswa (LKS) yang masing-masing dibuat dalam 4 kali pertemuan dan sebelumnya telah dilakukan validitas isi instrumen oleh validator ahli. Dalam hal ini perangkat telah dinyatakan valid dan dapat digunakan sebagai instrument untuk pembajaran pendekatan kontekstual. Adapun hasil validitas dilakukan validasi lansung oleh validator ahli mengenai tes pemahaman konsep fisika. Dalam hal ini tes dibuat dalam bentuk esai tes. Tes ini terdiri 7 nomor soal esai yang diberikan, ada 5 nomor yang dinyatakan valid. Tes ini merupakan tes yang ditekankan pada isi pemahaman konsep fisika.

Berdasarkan pada posttest yang diberikan pada kelas eksperimen dan kelas kontrol maka diperoleh nilai minimum untuk kelas eksperimen adalah 7 dan nilai maksimum adalah 18. Nilai rata-rata untuk kelas eksperimen sebesar 16,62 dan nilai standar deviasi sebesar 0,97. Pada kelas kontrol diperoleh nilai minimum sebesar 7 dan nilai maksimum 18, nilai rata-rata adalah 15,00 dan standar deviasi adalah 2,12. hasil posttest disajikan pada Tabel 2.

TABEL 2 HASIL POSTTEST KELAS EKSPERIMEN DAN KELAS KONTROL

\begin{tabular}{lcc}
\hline \multirow{2}{*}{ Uraian } & Kelas Kontrol & $\begin{array}{c}\text { Kelas } \\
\text { Eksperimen }\end{array}$ \\
\cline { 2 - 3 } Jumlah siswa & Tes Akhir & Tes Akhir \\
Nilai Minimum & 24 & 23 \\
Nilai Maksimum & 7 & 7 \\
Nilai Rata-rata & 18 & 18 \\
Simpangan Baku & 16,62 & 15,00 \\
& 0,97 & 2,12
\end{tabular}

Pengujian data normalitas data pada penelitian ini menggunakan Chi-kuadrat dengan kriteria penerimaan $\mathrm{X}^{2}$ hitung $<\mathrm{X}^{2}$ tabel, taraf signifikansi $a=0,05$ dan derajat kebebasan $d k$ $=\mathrm{k}-3$. Berdasaran hasil perhitungan posttest nilai $X^{2}$ hitung kelas esperimen adalah 5,56 dan kelas kontrol adalah 5,04 dengan $X^{2}$ tabel sebesar 7,81, data tersebut dapat dilihat pada Tabel 3.

TABEL 3 UJI NORMALITAS POSSTEST KELAS KONTROL DAN KELAS

\begin{tabular}{ccc} 
EKSPERIMEN & \multicolumn{3}{c}{ Posttest } \\
\hline Uraian & Eksperimen & Kontrol \\
\hline Kelas & 5,56 & 5,04 \\
$X^{2}$ hitung & 7,81 & 7,81 \\
$X^{2}$ tabel & & \\
Keterangan & & Normal
\end{tabular}

Berdasarkan hasil uji normalitas dengan menggunakan Chi-kuadrat, pada tabel diatas berdasarkan kriteria pengambilan keputusan maka $\mathrm{H}_{1}$ diterima. Hal ini menunjukan data pretest dan posttest berdistribusi normal.

Uji homogenitas digunakan untuk melihat suatu data apakah data tersebut berasal dari varian yang sama atau tidak. Oleh karena itu, uji homogenitas dilakukan dengan menggunakan $u \mathrm{ji}$ statistik $\mathrm{F}$ dengan taraf signifikansi $a=0,05$. Berdasarkan pengolahan data hasil analisis data dapat dilihat pada Tabel 4.

TABEL 4 UJI HOMOGENITAS POSTTEST PADA KELAS EKPERIMAN DAN KELAS

\begin{tabular}{|c|c|c|}
\hline Uraian & $\begin{array}{c}\text { Kelas } \\
\text { eksperimen }\end{array}$ & Kelas kontrol \\
\hline $\mathrm{F}_{\text {hitung }}$ & 1,14 & 1,14 \\
\hline $\mathrm{F}$ tabel & 2,01 & 2,01 \\
\hline Kriteria & \multicolumn{2}{|c|}{ Homogen } \\
\hline
\end{tabular}

Berdasarkan hasil uji homogenitas pada Tabel 4 dangan taraf signifikansi $a=0,05$, menghasilkan $\mathrm{F}$ hitung pada kelas eksperimen dan kelas kontrol sebesar 1,14 sedangkan $F$ tabel memiliki niai sebesar 2,01, berdasarkan hasil tersebut terihat bahwa $\mathrm{F}_{\text {hitung }}<\mathrm{F}$ tabel, sehingga dapat disimpulkan bahwa kelas eksperimen dan kelas kontrol berasal dari variansi yang sama (homogen).

Berdasarkan uji normalitas dan uji homogenitas yang teah diakukan pada posttest, diperoleh data yang berdistribusi normal dan homogeny sehingga dapat dianjutkan dengan uji hipotesis (dua pihak) dengan taraf signifikansi $a=0,05$, hasil uji-t dapat dilihat pada Tabel 5. 
TABEL 5 UJI-T (DUA PIHAK) KELAS EKSPERIMEN DAN KELAS KONTROL

\begin{tabular}{ccccc}
\hline Kelas & $\begin{array}{c}\text { Nilai } \\
\text { rata- } \\
\text { rata }\end{array}$ & $\mathrm{t}_{\text {nitung }} \mathrm{t}$ tabel & Keputusan \\
\hline $\begin{array}{c}\text { Kelas } \\
\text { eksperimen }\end{array}$ & 64,92 & & & \\
Kelas kontrol & 57,42 & 6,46 & 1,67 & $\mathrm{H}_{1}$ diterima
\end{tabular}

Kriteria pengujian dimana $\mathrm{H}_{0}$ diterima jika $\mathrm{t}$ $>\mathrm{t}(1-\mathrm{a})$ pada taraf signifikansi $\mathrm{a}=0,05$ dan $\mathrm{dk}=46$ dan untuk harga t lainya ditolak, dari daftar distribusi diperoleh tabel $=1,67$. Berdasarkan hasil perhitungan diketahui 6,46> 1,67, hal ini menunjukan bahwa nilai thitung berada diluar daerah penerimaan Ho. Dengan demikian $\mathrm{Ho}$ ditolak $\mathrm{H}_{1}$ diterima, artinya terdapat perbedaan pemahaman konsep antara siswa yang mengikuti pembelajaran pendekatan kontekstual dengan siswa yang mengikuti pembelajaran konvensional.

\section{B. Pembahasan}

Pendekatan kontekstual merupakan konsep belajar yang membantu guru mengaitkan antara materi yang diajarkan dengan situasi dunia nyata siswa dan mendorong siswa membuat hubungan antara pengetahuan yang dimilikinya dengan penerapan dalam kehidupan mereka sehari-hari. Pembelajaran kontekstual bertujuan memotivasi siswa untuk memahami makna materi pelajaran yang dipelajarinya dengan mengaitkan meteri tersebut dengan konteks kehidupan mereka sehari-hari sehingga siswa memiliki pengetahuan yang dapat diterapkan (ditransfer) dari satu permasalahan ke permasalahan yang lain.

Penelitian ini bertujuan untuk menguji siksifikan perbedaan pemahaman konsep siswa kelas VIII pada konsep cahaya antara kelas yang mendapatkan pembelajaran pendekatan kontekstual dengan kelas yang mendapatkan pembelajaran konvensional di SMP Negari 19 Palu. Perlakuan ini dilakukan untuk melihat bagaimana pemahaman konsep pada materi cahaya apakah ada perbedaan atau tidak antara pembelajaran pendekatan kontekstual den pembelajaran konvensional.

Hasil uji hipotesis dengan menggunakan uji-t (uji dua pihak) diperoleh nilai thitung untuk kelas eksperimen dan kelas kontrol pada posttest sebesar 6,46 dan tabel sebesar 1,67. Pada taraf signifikansi $a=0,05$. Hal ini menunjukkan thitung $=6,46>$ tabel $=1,67$ yang berarti Ho ditolak $\mathrm{H}_{1}$ diterima. Dengan kata lain, terdapat perbedaan pemahaman konsep antara siswa yang mengikuti pembelajaran dengan pendekatan kontekstual dengan siswa yang mengikuti pembelajaran konvensional. Penggunaan pendekatan kontekstual, dalam hal pelaksanaanya menuntut siswa dapat berperan aktif selama proses pembelajaran berlansung. Penyampaian materi dari guru juga sangat penting sebeum proses pembelajaran dimulai, sehingga memberi pengatahuan awal bagi siswa untuk lebih memudahkan dalam proses pembelajaran. Dari hasil uji hipotesis yang diperoleh menunjukkan bahwa nilai pada kelas eksperimen lebih besar dibandingkan dengan nilai pada kelas kontrol. Berdasarkan taraf nyata pada uji-t terdapat pengaruh pada pembelajaran pendekatan kontekstual dengan pembelajaran konvensional.

Kelebihan dari pembelajaran pendekatan kontekstual, pembelajaran ini dapat memberikan kesempatan pada siswa untuk lebih aktif mengembangkan kemampuan dan kreaktifitas sendiri secara mandiri, bertanggung jawab baik dalam individu maupun kelompok, saling bekerja sama dan melakukan penemuan sendiri. Membantu siswa untuk memahami bahan ajar secara lebih mudah, dan memperkuat penyimpanan materi yang telah disampaikan kepada siswa [2].

Penerapan pembelajaran ini, peneliti juga mendapatkan kesulitan yaitu sulit mengontrol siswa di dalam kelas, karena terlalu banyaknya tugas siswa diluar mata pelajaran fisika. Selain itu, walaupun sudah mengatur alokasi waktu yang cukup masih saja memerlukan waktu yang lebih banyak sehingga pencapaian hasil yang kurang maksimal.

Keunggulan pembelajaran konvensional yang diterapkan di kelas kontrol adalah: (1) merupakan teknik yang cukup bagus untuk memahami isi pelajaran; (2) dapat menantang kemampuan siswa serta memberikan kepuasan untuk menemukan pengetahuan baru bagi siswa; (3) dapat meningkatkan aktivitas pembelajaran siswa; (4) dapat membantu siswa untuk bagaimana mentransfer pengetahuan mereka untuk memahami masalah dalam kehidupan nyata; dan (5) dapat membantu siswa untuk mengembangkan pengetahuan barunya. Sedangkan kekurangan dari pembelajaran konvensional ini adalah guru kesulitan dalam merubah gaya mengajar; (1) Memerlukan lebih banyak waktu untuk siswa dalam memecahkan masalah, jika model tersebut baru diperkenalkan dikelas; (2) Setiap kelompok boleh menyelesaikan tugas sebelum atau sesudahnya; (3) Sukar menerapkan pembelajaran konvensional dalam semua kelas 
serta; (4) Kesulitan dalam menilai pelajaran. [5].

Di luar permasalahan yang menyangkut kekurangan model yang digunakan, model ini juga baik untuk digunakan disekolah agar siswa lebih aktif dalam proses belajar dibandingkan model-model yang sebelumnya dilakukan disekolah dimana siswa lebih banyak mendengarkan.

Pemahaman konsep muncul dari hasil evauasi dan reflaksi diri sendiri. Dengn demikian, pemahaman sebagai presentasi hasil pembelajaran menjadi sangat penting [6], dalam pembelajaran fisika bukan hanya sebagai kumpulan pengetahuan yang tersusun secara sistematik tetapi juga yang terpenting sebagai suatu proses. Selain itu memberi gambaran bahwa pendekatan kontekstual mempunyai pengaruh terhadap anggapan siswa pada mata pelajaran fisika [7]. Untuk mengetahui pengaruh pendekatan CTL melalui metode eksperimen dapat ditinjau dari keaktifan dan gaya belajar yang melibatkan pencarian jawaban atas penyelesaian terhadap suatu pertanyaan [8].

Mengetahui kemampuan siswa dalam memahami konsep fisika maka perlu diadakan penilaian terhadap pemahaman konsep dalam pembelajaran. Tentang penilaian perkembangan siswa dicantumkan indikator dari kemampuan pemahaman konsep sebagai hasil belajar, Indikator tersebut adalah: 1) Menyatakan ulang sebuah konsep; 2) Mengklasifikasikan objek menurut sifat-sifat tertentu sesuai dengan konsepnya; 3) Mengaplikasikan konsep atau algoritma pemecahan masalah [3].

Kemampuan menyatakan ulang sebuah konsep adalah kemampuan siswa untuk mengungkapkan kembali apa yang telah dikomunikasikan kepadanya, dimana pada saat siswa belajar maka siswa mampu menyatakan ulang maksud dari pelajaran itu. Kemampuan mengklafikasikan objek menurut sifat-sifat tertentu sesuai dengan konsep adalah kemampuan siswa mengelompokkan suatu objek menurut jenisnya berdasarkan sifat-sifat yang terdapat dalam materi. Siswa belajar suatu materi dimana siswa dapat mengelompokkan suatu objek dari materi tersebut sesuai sifat-sifat yang ada pada konsep. Kemampuan mengklafikasikan konsep atau algoritma ke pemecahan masalah adalah kemampuan siswa menggunakan konsep serta prosedur dalam menyelesaikan soal yang berkaitan dengan kehidupan sehari-hari. Dalam pembelajar siswa mampu menggunakan suatu konsep untuk memecahkan masalah.

\section{KESIMPULAN DAN SARAN}

V.

\section{A. Kesimpulan}

Berdasarkan hasil penelitian dan analisa data terdapat perbedaan pembelajaran pendekatan kontekstual dibandingkan dengan pembelajaran konvensional. Dimana terjadi peningkatatan yang lebih besar pada kelas eksperimen dibandingkan dengan kelas kontrol. Dalam proses pembelajaran pendekatan kontekstual pada kelas eksperimen siswa dihadapkan dengan permesalahan nyata yang dapat mengembangkan hubungan dalam bekerja kelompok, dan dapat menemukan sendiri jawaban atau konsep. Oleh karena itu, dapat disimpulkan bahwa terdapat pengaruh pada pembelajaran pendekatan kontekstual dengan pembelajaran konvensional terhadap pemahaman konsep fisika pada siswa kelas VIII SMP Negeri 19 Palu.

\section{B. Saran}

Berdasarkan hasil penelitian yang telah diperoleh selama melakukan proses pembelajaran, maka penulis menyarankan agar guru bidang studi fisika dapat menerapkan model pembelajaran kontekstual untuk meningkatkan hasil belajar fisika. Model pembelajaran kontekstual ini agar dapat dijadikan alternatif pembelajaran di sekolah untuk mata pelajaran lainnya.

\section{DAFTAR PUSTAKA}

[1] Yatim dan Riyanto. Paradigma Baru Pembelajaran. Kencana Perenada Media Grup. Jakarta. 2009.

[2] Sanjaya Wina. (2009). Strategi Pembelajaran Standar Proses Pendidikan. Kencana Perenada Media Grup. Jakarta.

[3] Mardianti. "Pengaruh Pembelajaran Kontekstual Terhadap Pemahaman Sisiwa Dalam Konsep Bunyi". Jurnal Pendidikan Fisika. 2011.

[4] Sudjana. Metode statistika, Edisi 6. Tarsito: Bandung. 2005.

[5] Efi. "Pengaruh Penggunaan Metode Mind Mapping Terhadap Keterampilan Berfikir Kreatif Siswa Kelas X SMA Negeri 2 Balaesang". Jurnal Pendidikan Fisika. 2016.

[6] C.J. Wening. "A pramework for teaching the nature of science". Journal of physics teacher education online. 3(3). 3-10. Avaiable at:http://www.phy.ilstu.edu/jpteo. 2006.

[7] Lonas, dkk. "Prior Knowledge Influence On Self Explanation Effectiveness When Solving: An Exploratory Study In Science Learning". 
International Journal Teaching And Learning In Higher Education. 2012.

[8] Parmono. "Pembelajaran Fisika Dengan Pendekatan CTL Melalui Metode Eksperimen
Dan Demontrasi Ditinjau Dari Kreativitas dan Gaya Belajar Siswa". Jurnal pendidikan fisika. Vol. 2, No. 1, 2013. 